\title{
Two years experience of a multidisciplinary approach for pediatric thrombosis in a tertiary referral center*
}

\section{Pediatrik tromboza multidisipliner yaklaşım, üçüncü basamak referans merkezin 2 yıllık deneyimi}

\author{
Rumeysa Tuna $^{1}\left(\mathbb{D}\right.$, Mustafa Bilici $^{1}$ (D), Osman Kipoğlu² (D), Orhan Coşkun² (D), \\ Zuhal Bayramoğlu ${ }^{3}$ (D), Süheyla Ocak ${ }^{1}$ (D), Deniz Tuğcu' ${ }^{1}$, Serap Karaman ${ }^{1}$ (i),

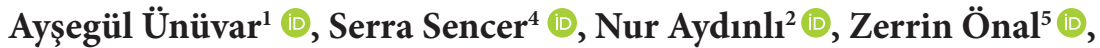 \\ Zeynep Yürük Yıldırım ${ }^{6}$ (D), Kemal Nişli ${ }^{7}$ (D), Rukiye Eker Ömeroğlu ${ }^{7,8}$ (D), Aygün Dindar ${ }^{7}$ (D)

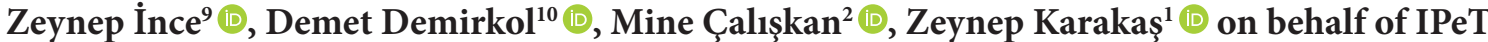 \\ study group ${ }^{* *}$
}

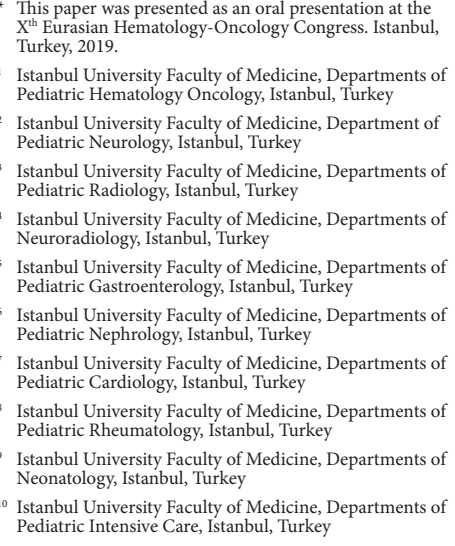

\section{ABSTRACT}

Pediatric thrombosis has unique characteristics due to its epidemiology, pathophysiology and treatment considerations. Children diagnosed with thrombosis should be evaluated by a multidisciplinary team at the level of diagnosis, treatment, and follow-up. Here we present our 2 years experience of pediatric thrombosis patients with a multidisciplinary thrombosis council management. We retrospectively reviewed case presentations and recommendations of monthly thrombosis council for 61 children ( 95 admissions) between November 2017 and August 2019. The male/female ratio was 1.54 and children and adolescents were the majority of evaluated 61 patients. Based on patients' clinical and radiological status, treatment and prophylaxis periods were determined. Cerebral arterial and sinovenous thrombosis were more common in our pediatric thrombosis council cases. Acquired risk factors for thrombosis were more common than congenital thrombophilia. Infection and elevated Factor VIII were commonest, respectively. Thirty-nine patients (64\%) received primary or secondary prophylaxis with vitamin $\mathrm{K}$ antagonists, aspirin or LMVH for different periods. Further studies on treatment and prophylaxis management are needed for the improvement of evidence-based guidelines in pediatric thrombosis. Multidisciplinary councils may improve patient care for pediatric patients with complicated thrombosis.

Keywords: Pediatric thrombosis, treatment, prophylaxis, multidisciplinary management

ÖZ

Pediatrik tromboz epidemiyolojisi, patofizyolojisi ve tedavi öncelikleri nedeniyle erişkin tromboz yönetiminden çok farklı özelliklere sahiptir. Tromboz teşhisi konan çocuklar, multidisipliner bir ekip tarafından tanı, tedavi ve takip süresince değerlendirilmelidir. Burada pediatrik tromboz hastalarımızın yönetildiği 2 yıllık multidisipliner tromboz konseyi deneyimimizi sunuyoruz. Kasım 2017-Ağustos 2019 tarihleri arasında 61 çocuk (95 başvuru) için tromboz konseyi olgu sunumlarını ve konsey sonuçlarını geriye dönük olarak inceledik. Değerlendirilen hastalarda erkek/kadın oranı 1,54 saptandı, çocuklar ve adolesanlar çoğunluktaydı. Hastaların klinik ve radyolojik durumlarına göre tedavi ve profilaksi süreleri belirlendi. Olgularımız içinde serebral arteriyel ve sinovenöz tromboz olguları daha fazla idi. Kazanılmıs risk faktörleri, kalıtsal olanlardan daha fazla olup infeksiyon ve Faktör VIII yüksekliği sık idi. Otuz dokuz hastaya (\%64) farklı süreler boyunca K vitamini antagonistleri, aspirin veya LMVH ile primer veya sekonder profilaksi uygulandı. Pediatrik trombozda kanıta dayalı kılavuzların iyileştirilmesi için tedavi ve profilaksi yönetimi üzerine daha fazla çalışmaya ihtiyaç vardır. Multidisipliner tromboz konseyi komplike pediatrik trombozlu çocuk hastalarda hasta bakımını iyileştirebilir. Anahtar Kelimeler: Pediatrik tromboz, tedavi, proflaksi, multidisipliner yönetim 


\section{INTRODUCTION}

Pediatric thrombosis has unique characteristics due to its epidemiology, pathophysiology and treatment considerations. Venous thromboembolism (VTE) incidence in children is 0.07 to 0.14 per 10000 children (1). Although it is rare in the general population, 1001000 times higher rates in hospitalized children are seen. Especially 2 risky age groups are determined; newborns due to their immature coagulation systems and interventions such as umbilical vein catheterization and adolescents for hormonal changes, obesity and trauma (2). The most common causative factors are central venous catheters in newborns and older children. Evidence-based guidelines are mostly extrapolated from adult studies (1). Recommendations on optimal drug choice, treatment duration and risk assessment in children have evidence gaps. Pediatric thrombosis management requires expertise and a multidisciplinary approach. The risk and benefits of anticoagulation for the treatment or prophylaxis of thrombosis in children should be evaluated on a patient-specific basis. We present our 2 years' experience of a multidisciplinary pediatric thrombosis council in a tertiary referral center.

\section{METHOD}

Complicated pediatric thrombosis cases were evaluated in a monthly multidisciplinary council in Istanbul University Faculty of Medicine. Members were from pediatric hematology-oncology, pediatric radiology, and neuroradiology in addition to other pediatric subspecialties (pediatric rheumatology, pediatric nephrology, neonatology, pediatric neurology, pediatric cardiology, pediatric endocrinology, pediatric intensive care, and pediatric gastroenterology).

We retrospectively reviewed case presentations and recommendations of the council for 61 children (95 admissions) between November 2017 and August 2019. Evaluated cases in thrombosis council included; cerebral thrombosis, unprovoked thrombosis of different sites, provoked thrombosis of any site in case of comorbidities or persistent risk factors, patients in risky situations with family history without a personal history of thromboembolism. All patients were re-evaluated by the radiologist at the multidisciplinary council for primary diagnosis and/or ongoing management. All patients were examined for hereditary and acquired thrombophilia factors $(3,4)$. Multidisciplinary council determined treatment, prophylaxis and monitoring periods based on patients' clinical and radiological status.

\section{RESULTS}

The male/female ratio was 1.54 of evaluated 61 patients. Twenty-two patients were re-evaluated at follow-up for treatment management or reporting outcome. Five of the patients (8\%) were newborns (0-1 month), 10 (16\%) were infants ( 1 month to 2 years), 23 (37\%) were children (2 to 12 years), 22 (36\%) were adolescents (12 to 18 years) and 2 (3\%) were young adults (22 and 26 years, respectively) at diagnosis. All patients were re-evaluated by the radiologist at the multidisciplinary council for primary diagnosis or ongoing management. Eight of the 61 patients had thrombosis of more than one site. Cerebral arterial infarction and cerebral sinovenous thrombosis were the most common diagnoses (Table 1). Six patients were evaluated for anticoagulation prophylaxis without a personal history of the previous thrombosis; 5 for pre-hormone replacement therapy (HRT) evaluation and 1 for strong family history, respectively. Fifty patients had concomitant diseases which increased the risk of thrombosis. Infection, rheumatologic disease, and catheterization were common concomitant diseases (Table 2). High factor VIII and homocysteine levels were commonest underlying thrombophilia factors, respectively (Table 3). Based on patients' clinical and radiological status, treatment and prophylaxis periods were determined. Thirty-nine patients (64\%) received primary or secondary prophylaxis with vitamin $\mathrm{K}$ antagonists (VKA), Aspirin or low molecular weight heparin (LMWH) for different periods.

None of the patients had bleeding or thrombosis related mortality except the patient with hepatic cirrhosis. She developed hepatic vein and IVC (inferior vena cava) thrombosis. Lupus anticoagulant and homozygous Factor V Leiden mutation were detected. She died due to cirrhosis related systemic complications. 
Table 1. Patients' Diagnosis

\begin{tabular}{|l|c|}
\hline Patient's Diagnosis & $\begin{array}{c}\text { Patient Number } \\
\text { (Percentage) }\end{array}$ \\
\hline Cerebral arterial infarction & $22(36 \%)$ \\
\hline Cerebral sinovenous thrombosis & $20(32 \%)$ \\
\hline Portal vein thrombosis & $5(8 \%)$ \\
\hline Renal vein thrombosis & $4(6.5 \%)$ \\
\hline Extremity deep vein thrombosis & $4(6.5 \%)$ \\
\hline Cardiac thrombosis & $3(5 \%)$ \\
\hline Hepatic vein thrombosis & $2(3 \%)$ \\
\hline Recurrent catheter thrombosis & $2(3 \%)$ \\
\hline Peripheral arterial thrombosis & $2(3 \%)$ \\
\hline Pulmonary Embolism & $1(1.5 \%)$ \\
\hline
\end{tabular}

Table 2. Patients with concomitant diseases

\begin{tabular}{|l|c|}
\hline Concomitant Diseases & $\begin{array}{c}\text { Patient Number } \\
\text { (Percentage) }\end{array}$ \\
\hline Infection & $17(27 \%)$ \\
\hline Trauma & $5(8 \%)$ \\
\hline Rheumatologic disease & $6(10 \%)$ \\
\hline Congenital heart disease & $5(8 \%)$ \\
\hline Catheterization & $6(10 \%)$ \\
\hline Kidney disease & $4(6.5 \%)$ \\
\hline Malignancy & $3(5 \%)$ \\
\hline Hemoglobinopathy & $2(3 \%)$ \\
\hline Dehydration & $2(3 \%)$ \\
\hline
\end{tabular}

Table 3. Underlying congenital and acquired thrombophilia factors*

\begin{tabular}{|l|c|}
\hline Thrombophilia Factors & $\begin{array}{c}\text { Patient Number } \\
\text { (Percentage) }\end{array}$ \\
\hline High Factor VIII level & $17(27 \%)$ \\
\hline High Homocysteine level & $14(23 \%)$ \\
\hline High Fibrinogen level & $9(14 \%)$ \\
\hline $\begin{array}{l}\text { Factor V leiden } \\
\text { mutation }\end{array}$ & $\begin{array}{c}\text { (16\%) }(1 / 9: \text { homozygous/ } \\
\text { heterozygous) }\end{array}$ \\
\hline $\begin{array}{l}\text { Prothrombin 20210A } \\
\text { mutation }\end{array}$ & $8(6.5 \%)$ (all heterozygous) \\
\hline $\begin{array}{l}\text { Protein C deficiency } \\
\text { Mild) }\end{array}$ & $4(13 \%)$ \\
\hline Protein S deficiency (Mild) & $6(10 \%)$ \\
\hline $\begin{array}{l}\text { Antithrombin III } \\
\text { deficiency (Mild) }\end{array}$ & $2(3.25 \%)$ \\
\hline Hyperlipidemia & \\
\hline Lupus anticoagulant & \\
\hline
\end{tabular}

${ }^{\star}$ Lipoprotein (a) levels can not be measured in our center

\section{DISCUSSION}

Cerebral arterial and sinovenous thrombosis were more common in our pediatric thrombosis council cases. It was associated with difficulties that pediatricians should face in the treatment of cerebral thrombosis and our center's crucial position as a tertiary referral center where complicated cases were referred. The most common age groups were children and adolescents in our council cases which was different from the general population. Even though thrombosis incidence is higher in newborns and adolescents (2), neonates did not form the majority in our council cases as most of the neonatal thrombosis could be solved without anticoagulation therapy with the displacement of umbilical vein catheters. In our council cases, acquired risk factors for thrombosis were more common than congenital ones, which was consistent with the literature $(5,6)$.

Besides its rarity, some call VTE "an epidemic of tertiary pediatrics" (7). Treatment strategies should be individualized as the course of VTE varies according to the underlying diseases and risk factors in children of different age groups (8). Patients with unprovoked VTE or provoked VTE and persistent risk factors, have more than $10 \%$ recurrent VTE per year $(8,9)$. The presence of single strong or combined inherited thrombophilia in pediatric patients has an association with VTE onset and recurrences $(4,10)$. Contributing thrombophilia factors like hyperhomocysteinemia, increased lipoprotein (a) and elevated plasma factor VIII at diagnosis should be reassessed during prophylaxis. The decision for prolonged anticoagulation to prevent recurrent VTE in children is an extremely challenging question considering bleeding or other complications. Preferred agents for prophylaxis in children are LMWH for short term, Aspirin or VKA for long term $(3,8)$.

\section{CONCLUSION}

Assessment of risk factors and multidisciplinary evaluation from a wider aspect can improve physicians' understanding and practice for better care of pediatric patients with complicated thrombosis. Clinical studies are needed to clarify the clinical importance of laboratory and imaging studies and the risk\&benefits of long term anticoagulation of pediatric patients whit thrombosis. 
Hakem Değerlendirmesi: Dış bağımsız.

Peer Review: Externally peer-reviewed.

Yazar Katkıları: Çalışma Konsepti/Tasarım- R.T., Z.K., D.T., S.K., A.Ü.; Veri Toplama- R.T., M.B., O.K., O.C.; Veri Analizi/Yorumlama- R.T., Z.K.; Yazı Taslağ1- R.T.; İçeriğin Eleştirel İncelemesi- Z.K.; Son Onay ve Sorumluluk- R.T., M.B., O.K., O.C., Z.B., S.O., D.T., S.K., A.Ü., S.S., N.A., Z.Ö., Z.Y.Y., K.N., R.E.Ö., A.D., F.D., Z.İ., D.D., M.Ç., Z.K.; Malzeme ve Teknik Destek- Z.B., S.S.; Süpervizyon- Z.K.

Author Contributions: Conception/Design of Study- R.T., Z.K., D.T., S.K., A.Ü.; Data AcquisitionR.T., M.B., O.K., O.C.; Data Analysis/InterpretationR.T., Z.K.; Drafting Manuscript- R.T.; Critical Revision of Manuscript- Z.K.; Final Approval and Accountability- R.T., M.B., O.K., O.C., Z.B., S.O., D.T., S.K., A.Ü., S.S., N.A., Z.Ö., Z.Y.Y., K.N., R.E.Ö., A.D., F.D., Z.İ., D.D., M.Ç., Z.K.; Technical or Material Support- Z.B., S.S.; Supervision- Z.K.

Çıkar Çatışması: Yazarlar çıkar çatışması beyan etmemişlerdir.

Conflict of Interest: Authors declared no conflict of interest.

Finansal Destek: Yazarlar finansal destek beyan etmemişlerdir.

Financial Disclosure: Authors declared no financial support.

\section{REFERENCES}

1. Monagle P, Cuello CA, Augustine C, Bonduel M, Brandao LR, et al. American Society of Hematology 2018 Guidelines for management of venous thromboembolism: treatment of pediatric venous thromboembolism. Blood advances. 2018;2(22):3292-316.

2. Newall F, Branchford B, Male C. Anticoagulant prophylaxis and therapy in children: current challenges and emerging issues. Journal of thrombosis and haemostasis : JTH. 2018.

3. Chalmers E, Ganesen V, Liesner R, Maroo S, Nokes T, et al. Guideline on the investigation, management and prevention of venous thrombosis in children. British journal of haematology. 2011;154(2):196-207.
4. Young G, Albisetti M, Bonduel M, Brandao L, Chan A, et al. Impact of inherited thrombophilia on venous thromboembolism in children: a systematic review and metaanalysis of observational studies. Circulation. 2008;118(13):1373-82.

5. Mahajerin A, Branchford BR, Amankwah EK, Raffini L, Chalmers E, et al. Hospital-associated venous thromboembolism in pediatrics: a systematic review and meta-analysis of risk factors and risk-assessment models. Haematologica. 2015;100(8):1045-50.

6. Jaffray J, Mahajerin A, Young G, Goldenberg $\mathrm{N}$, Ji L, et al. A multi-institutional registry of pediatric hospital-acquired thrombosis cases: The Children's Hospital-Acquired Thrombosis (CHAT) project. Thrombosis research. 2018;161:67-72.

7. Monagle P. Slow progress. How do we shift the paradigm of thinking in pediatric thrombosis and anticoagulation? Thrombosis research. 2019;173:186-90.

8. Monagle P, Chan AKC, Goldenberg NA, Ichord $\mathrm{RN}$, Journeycake JM, et al. Antithrombotic therapyin neonates and children: Antithrombotic Therapy and Prevention of Thrombosis, 9th ed: American College of Chest Physicians EvidenceBased Clinical Practice Guidelines. Chest. 2012;141(2 Suppl):e737S-e801S.

9. Rodger MA, Le Gal G. Who should get long-term anticoagulant therapy for venous thromboembolism and with what? Blood advances. 2018;2(21):3081-7.

10. Nowak-Gottl U, van Ommen H, Kenet G. Thrombophilia testing in children: What and when should be tested? Thrombosis research. 2018;164:75-8. 